ture information with the results of chemical and kinetic studies on these digestive enzymes.

Among the variety of contributions are papers by $P$. Desnuelle et al. characterizing the porcine chymotrypsins, M. Lazdunski et al., K. A. Walsh et al., and Elliott Shaw on the effects of various chemical modifications on trypsin and chymotrypsin, and S. Magnusson describing structural aspects of thrombin and prothrombin. R. Acher and J. Chauvet, B. Keil, and M. Laskowski present stimulating papers on the structure and activity of pancreatic and soybean trypsin inhibitor, and E. L. Smith et al. and M. Ottesen et al. interpret the results of chemical studies on tho subtilisins in the light of the crystallographically determined structure of subtilisin $\mathrm{BPN}^{\prime}$. 'The properties of pepsin are described in detailed papers by J. S. Fruton on specificity and steady-state kinetics, by W. H. Stein and G. E. Perlmann on various chemical studies and by J. R. Knowles et al. who review many of the data and propose a catalytic mechanism.

The volume also includes the second Linderstrom-Lang Gold Medal lecture by E. Katchalski, who deseribes tho use of matrix-bound enzymes to simulate in vivo microenvironments, and papers by $H$. Neurath on sequence homologies, by B. L. Vallee and S. H. Latt on ion replacement in metaloproteinases, and by $\mathbf{H}$. Zuber on thermophilic bacterial aminopeptidases. It is concluded with a section on the sulphydryl proteinases, S. Moore describing the chemical properties of streptococcal proteinase, T. Murachi and N. Takahashi describing those of stem bromelain, and B. G. Wolthers et al. interpreting the threc-dimensional crystallographic structure of papain, and discussing its specificity and catalytic mechanism.

This book is therefore neither a general introductory text nor a comprehensive integrated review of the field, but rather gives a series of detailed glimpses into the many areas under current active investigation by the various contributors. Its major shortcoming is its lack of substantial contributions on several important areas of the subject, such as the description and interpretation of the rapid-reaction kinetics and the primary and tertiary structures of a greater number of the enzymes. The contributions on pepsin clearly illustrate the limitations of the classical approaches of steady-state kinetics and chemical modification in the absence of detailed structural inforination, and it is therefore to be regretted that the infor mation of this nature which was presented at the symposium has not been more fully included in this volume. When taken together, however, with the collected papers from the discussion meeting on the "Structures and Functions of Proteolytic Enzymes" organized by the Royal Society a few months earlier (Phil. Trans. Roy. Soc., B, 257, $63 ; 1970$ ) which was much more structural in its approach, this book provides a clear picture of the present state of research on proteolytic enzymes, and is recommended to all those interested in this field.

David Shotion

\section{CLASSIFICATION OF COMMUNICATION}

Approaches to Animal Communication

Edited by T. A. Sebeok and A. Ramsay. (Approaches to Semioties, Vol. 1.) Pp. 261. (Mouton: The Hague and Paris, 1969.) 52 Dutch guilders.

THE chapters in this book are the summary statements of ten out of the seventeen participants in a symposium on animal communication arranged by the Wenner-Gren Foundation for Anthropological Research in June 1965. It is not clear from the introduction whether the papers have been re-written in the light of the discussion which must have followed when they were first presented, but the almost total absence of references of a later date than the meeting suggests that in the main they were not. This in turn makes one wonder whether they were worth publishing after such a long delay.

Classification schemes are nearly always tendentious subjects, and as the authors are almost exclusively concerned with them, one is bound to be critical of the opinions expressed. Animal communication is an extremely diverse field from which the expert selects the facets which interest him as a phonetician, field zoologist or whatever. 'The classifications proposed are therefore always biased by the author's predilections. A good classification should deepen an understanding by revealing relationships, but there seems little chance of this when the phenomena are so heterogenous. To quote Lenneberg, "communication can only be defined in somewhat arbitrary terms and it never represents a unified or even clearly related behavioural unity".

Gregory Bateson's opening "metalogue", "What is an Instinct ?", sets the right iconoclastic tone which is rarely. sustained in later papers. Moulton's classification of teleost acoustic communication is useful; Moles's consideration of the application of the concept of language to animals is to the point, and Carpenter's reconsideration of his field work on a variety of primates is interesting. The editors contribute on zoosemiotics. Quite the longest paper by far is Count's "Animal Communication in Man-Science; an Essay in Perspective" which I find impossible to evaluate because the central theme kept eluding me.

So the question remains: was this worth publishing? J. D. CARTHY

\section{ANIMAL DISTRIBUTION}

\section{Dynamic Zoogeography with Special Reference to Land Animals}

By Miklos D. F. Udvardy. Pp. xviii +445. (Van Nostrand Reinhold: New York and London, May 1970.) $163 s$.

Lrke de Lattin's Grundriss der Zoogeographie published three years ago, this book is modelled on Hesse's ecological approach to the subject. Udvardy is interested in problems relating to modern species and he stresses modern ecological factors influencing their dispersal and limitation. He gives examples of changes in distribution over periods of a few hundred years and of others as far back as the beginning of the Pleistocene glaciations, but he gives only at few lines to the possible influence of earlier geological and climatic alterations. His statement that "all of those dynamic processes which have been shown to have been active in the geological past are also acting at the present time" is without evidence or discussion to support it.

As a survey of ecological zoogeography and the historical zoogeography of the past million years it is a useful contribution. There are good sections on dispersal, barriers and colonization, with examples from both invertebrates and vertebrates. Udvardy himself has been chiefly interested in the ecological problems that have affected modern bird distribution. Computer techniques, the newest theories of animal refuges and island faunas are discussed, but, because Udvardy refuses to take sides, the discussion lacks vigour.

There is a very interesting chapter on aerography: the study of distribution areas. Techniques for making species distribution maps are discussed, and the influences of shape, structure and recent history on the patterns that emerge. Dynamic Zoogeography is lavishly illus. trated. But a diagram should either form an integral part of the text or should give a quick visual alternative to a long or difficult description. Complicated diagrams and diagrams with half a page of text to describe them defeat these objectives. Many of the diagrams in this 